Reynald Lemke - Walter H. Johns Graduate Fellowship

Rongzhou Man - William H. McCardell Memorial Scholarship

Emmanuel Mapfumo - University of Alberta Ph.D. Scholarship (Renewal)

Ian Nalder - Walter H. Johns Graduate

Fellowship

Terrance Osko - Walter H. Johns

Graduate Fellowship

Iwona Pawlina - Walter H. Johns

Graduate Fellowship

Richard Roth - Walter H. Johns Graduate

Fellowship

Myrna Salloum - Province of Alberta

Graduate Scholarship

Barbara Sander - University of Alberta

$\mathrm{Ph}$.D. Scholarship

Geoffrey Stuart-Smith - Province of

Alberta Graduate Scholarship

Yingfang Wang - University of Alberta

Ph.D. Scholarship

Xiaohong Yao - Herbert and Jeanette

Hall Graduate Scholarship

Recent M.Sc. Graduates (Fall 1995)

Andy Miller, Jim Butler, supervisor

Howard Delong, Vic Lieffers, supervisor

Christine Hansen, Bruce Dancik, supervisor

Recent Ph.D. Graduates (Fall 1995)

Lesley P. Curthoys-Brown, Jim Butler, supervisor

Daniel Farr, Jim Butler, supervisor

New Graduate Students

Jonathon Wilkinson, M.Sc. Forest Fire

Science, Paul Woodard, supervisor

Yangou Qin, M.Sc. Forest Measurements,

Steve Titus, supervisor

Geoffrey J. Stuart-Smith, M.Sc. Forest

Ecology, Ellen Macdonald, supervisor

Barbara Sander, Ph.D. Fire Ecology,

Ross Wein, supervisor

Richard M. Ruth, Ph.D. Wildlife

Management, Robert Hudson, supervisor

Isabelle Richardson, M.Sc. Outdoor

Recreation, Jim Butler, supervisor

P.B. George Peterson, M.Sc. Ecology,

Macdonald and Kershaw, supervisor's

Michael L. Liston, Ph.D. Fire Ecology,

Ross Wein, supervisor

Jamie K. Honda-McNeil, M.Sc. Ecology,

Ross Wein, supervisor

Karen A. Harper, Ph.D. Forest Ecology,

Ellen Macdonald, supervisor

Huapeng Chen, Ph.D. Wildlife Management, Robert Hudson, supervisor

Allan B. Bertschi, M.Sc. Forest Hydrology,

Richard Rothwell, supervisor

\title{
PROFESSIONAL DIRECTORY \\ DIRECTOIRE PROFESSIONNEL
}

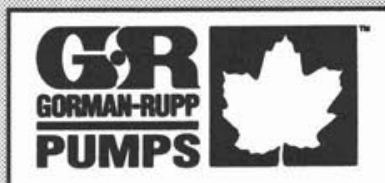

\author{
Canadian \\ Manufacturers \\ of Municipal and \\ Forestry Fire Pumps
}

Gorman-Rupp of Canada Limited

70 Burwell Road, St. Thomas, Ont.

Tel. (519) 631-2870 Fax (519) 631-4624
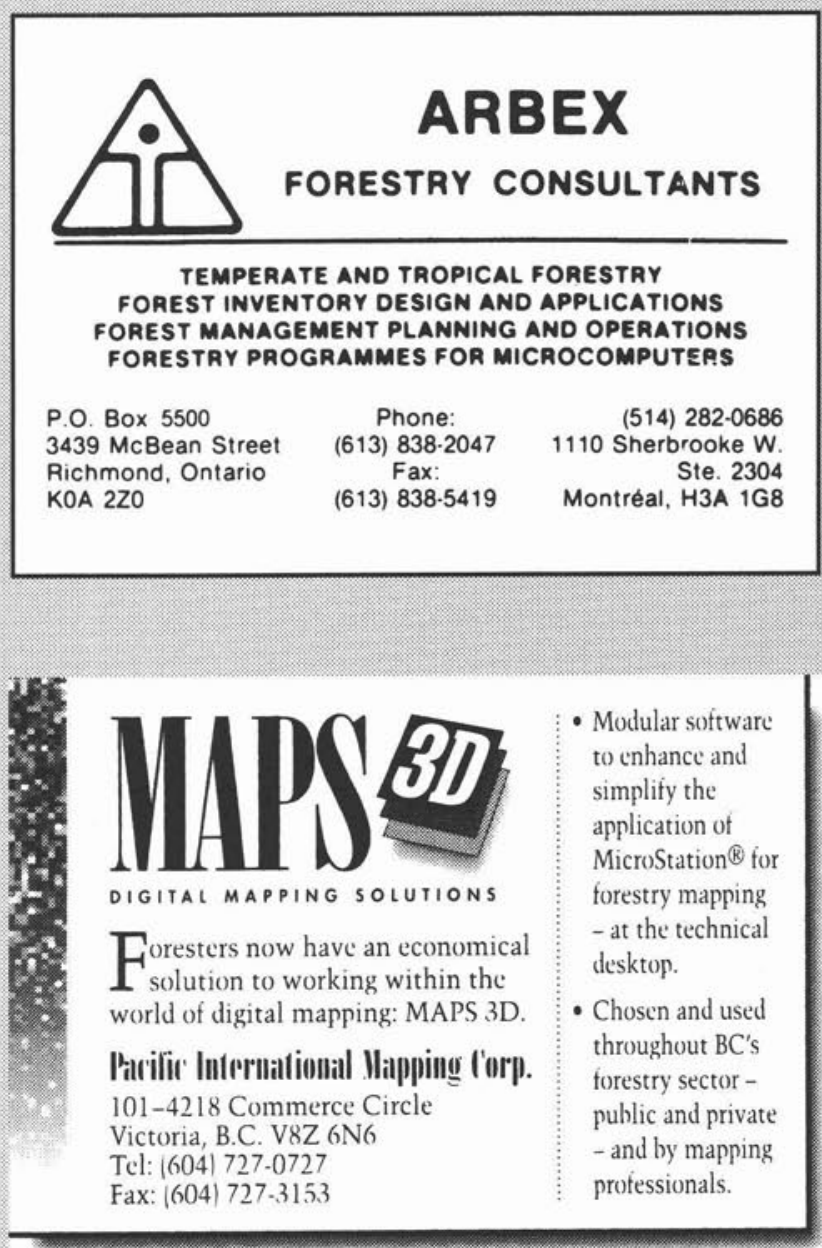

\section{Recent Forestry-related Publications}

Huang, S. and J.D. Heidt. 1995. Variable density yield relationships for deciduous stands: Original data, fit statistics and residual plots. Land and Forest Services, Alberta Environmental Protection, Tech. Rep. Pub. No. T/322.

Huang, S. and S.J. Titus. 1995. An individual tree diameter increment model for white spruce in Alberta. Can. J. For. Res. 24: 1455-1465.

Landhausser, S.M. and V.J. Lieffers. 1994. Competition between Calamagrostis canadensis and Epilobium angustifolium under different soil temperature and nutrient regimes. Can. J. For. Res. 24: 2244-2250.

Lieffers, V.J. 1995. Ecology and dynamics of boreal forest understory species and 
their role in partial-cut silviculture. Pp. 33-39. In: Proceeding: Innovative silviculture systems in Boreal Forest. IUFRO and Can. For Serv. publication. Clear Lake publication, Edmonton.

Luckert, M.K. and D. Haley. 1995. The allowable cut effects as a policy instrument in Canadian forestry. Can. J. For. Res. 24: 1821-1849.

Mugasha, A. G. and D. J. Pluth. 1994. $\mathrm{N}$-labeled urea fertilization of a tamarack/black spruce mixed stand on a drained minerotrophic peatland: $\mathrm{N}$ in soil and tree uptake. For Ecol. Mgmt. 68: 339-351.

Mugasha, A.G. and D.J. Pluth. 1994. Distribution and recovery of $\mathrm{N}$-urea in a tamarack/black spruce mixed stand on a drained minerotrophic peatland. For. Ecol. Mgmt. 68: 353-363.

Yang, R.C. and F.C. Yeh. 1995. Pattern of gene flow and geographic structure in Pinus contorta Dougl. Forest Genetics 2: 65-75.

Yazdani, R., F.C. Yeh and J. Rimsha. 1995. Genomic mapping of Pinus sylvestris (L.) using random amplified ploymorphic DNA. For. Genet. 2:1-10.

Of special note, the Department has a new home page. It can be found at the following address: http://www.rr.ualberta.ca/

\section{Paul M. Woodard, Ph.D., R.P.F.}

\section{BRITISH COLUMBIA} Forestry International Programs

The Forestry International Programs Office has been overwhelmed at the response it has received from Forestry undergraduates in response to its promotion of International and Canadian exchange opportunities.

\section{Outstanding turnout of Forestry Students for Information Session}

In a recent information session which outlined the application and selection process for studying abroad, 41 undergraduates were in attendance. Mary Watt, UBC's Education Abroad Program coordinator said for the proportion of undergraduates enrolled in Forestry, the turnout to the meeting was extraordinary.

\section{$U B C$ Wide Exchange Program and \\ Forestry's Current Involvement}

Last year 130 students at UBC participated in an exchange. Projections for the coming academic year predict that this number will increase to 150 students university wide. Within the Forestry faculty, there are currently two students away on exchange, one at the Swedish University of Agricultural Sciences, and the other at the University of Melbourne. Forestry's international programs hopes to facilitate more of its students to take advantage of these programs.

Forestry students currently have a choice of 15 schools throughout the world in which they can choose to study for a year. The exchange normally takes place in their third year of academic study. There are exchanges in several schools in Australia, New Zealand, Asia, Europe, Latin America, and the United States. There is also a Canadian university reciprocal exchange program where a UBC student could do part of their studies at another Canadian university.

\section{UBC International Scholarship Program in Place}

UBC is strongly supporting international programs within the University. A scholarship program is in place which guarantees students who have been selected to study abroad between $\$ 500-\$ 1500$ if they fulfill a minimum $75 \%$ average in the year preceding their exchange. This is meant to offset some of the travel and living costs associated with the exchange program. International Programs within Forestry also hopes to provide a few of its selected exchange students with modest scholarships to further enable students to take advantage of the program.

Beginning in January 1996, International Programs will be contacting faculty advisors to discuss and advise how transfer credit and courses can be planned for outgoing exchange students. Questions or suggestions for new potential exchanges should be directed to Sandra Schinnerl, Assistant Director of Forestry International Programs, at (604) 822-9627.

\section{Forest Resources Management Department}

Dean Clark Binkley was recently involved in a review of the Centre for International Forestry Research (CIFOR) in Bogor, Indonesia. CIFOR is one of the two forestry units in the Consultative Group on International Agricultural Research. Dean Binkley was also involved in a review for the Ontario Council of Graduate Studies of the new University of Toronto Master of Forest Conservation program.
Dr. Andrew Howard has just returned from Bolivia and Columbia where he traveled for field visits as part of his research project looking at the distribution of revenues within the forest sector and potential financial returns from alternative silvicultural prescriptions applied to natural forests in the Amazon Basin. $\mathrm{He}$ also gave a talk at a conference sponsored by the Colombians on education reform of forestry in Latin America and the Caribbean at both the technical and university levels.

Dr. G. Cornelis van Kooten recently visited the Beijer Institute and Association of Forest Industry offices in Stockholm, the Swedish Agricultural University in Uppsala, and the University of Umea while conducting research on a CFS project to examine Swedish forest policy and silvicultural successes.

\section{Forest Sciences Department}

John Carlson (Forest Sciences and the Biotechnology Lab at UBC) recently traveled to China to lecture for 7 days at the Northeast Forestry University (NEFU) in Harbin, PRC. The NEFU is perhaps the largest university in the world dealing specifically with forestry - all aspects of forestry from ecology to engineering. Dr. Carlson lectured for 17 hours to a group of staff and students interested in genetic diversity, genetic engineering and marker-assisted selection in their new Open Laboratory of Forest Ecology which has been established at NEFU as a national key lab and to which Dr. Carlson has been officially appointed as an advisor. Dr. Carlson was accompanied by LiJuan Sun, a graduate student from NEFU who is co-supervised at UBC by Carlson and Dr. Bart van der Kamp. Mrs. Sun served as expert translater and made the visit a success. Numerous avenues for collaboration were discussed. Faculty and students from NEFU home to visit UBC in the future for short periods of training and research collaboration.

Dr. Carlson gave invited talks in August at the IUFRO 20th World Forestry Congress in Tampere, Finland and at the joint meeting of the Western Forest Genetics Association and the Canadian Tree Improvement Association at the University of Victoria.

In October, Dr. Hamish Kimmins lectured at the Alberta Institute of Advanced Forest Management on modelling the sustainability of forest ecosystems. In 
November, Dr. Kimmins lectured at the Silviculture Institute of $\mathrm{BC}$ on predicting long term sustainability of ecosystem function and yield. At the end of November, he presented an invited paper at the Conservation of Northern Forests Symposium at the University of Toronto.

Dr. Gene Namkoong spoke at the European Forest Genetic Conservation Meeting. This meeting is related to the Canadian efforts on Boreal Forest Genetic Conservation Meeting which was held in Toronto this past summer, all of which is related to the International Conference and Process on Plant Genetic Resources.

\section{Wood Science Department}

In September, Dr. Linda Abraham successfully completed her Ph.D. in the Forest Products Biotechnology Program. Linda's research was on "Functions of a proteinase secreted by the sapstaining fungus Ophiostoma piceae." Comments from the examination panel were very positive: "The oral and written presentations reflect a student of high calibre". This is a significant graduation because Linda is the first Ph.D. graduate in the Forest Products Biotechnology program which began operations in 1990 .

Mr. Andrew Rozsa from CSIRO Division of Forest Products, Australia spent a month with Dr. Stavros Avramidis carrying out exploratory research in the area of radio-frequency/vacuum drying of eucalyptus lumber.

Drs. J.D. Barrett, Frank Lam and Helmut Prion attended the 39th annual meeting of the Canadian Standards Association Technical Committee on Engineering Design in Wood in Toronto. The group participated in the development of background information in support of changes to the timber design code aiming to improve the reliability and efficiency of timber structures. The group's activities included: (1) Development of model procedures relating specified strengths to characteristic structural properties; (2) Effect of double incising on bending strength of lumber (F. Lam and P. Morris); (3) Shear strength of Canadian softwood structural lumber (F. Lam, H. Yec and J. D. Barrett) and, (4) Top truss chord members design proposal (W. Lau, J. D. Bar).

Susan B. Watts, Ph.D., R.P.F.

\section{STUDENT DIRECTORY}

MCPHERSON, Scott. Box 281, 21 Classic Ave., Toronto, ON M5S 2Z3. Tel: (416) 598-3593 (until May 1996).

Graduating May 1996, B.Sc.F. University of Toronto. Ambitious and motivated. Solid computer, organization and leadership skills. Experience: pest monitoring and management, site prep. and conifer release trials, tree planting. Land Class 1 \& 3 Exterminator Licences. Awards: Dean's Admission Scholarship, R.C. Hosie Award for Dendrology and Silvics. CIF member. Willing to relocate anywhere.

DILLENBECK, Darren. 666 Mitchell St., Fredericton, New Brunswick E3B 3S6. Tel: (506) 455-7820, Email: m8v@unb.ca

I am graduating in the spring of 1996 with a Bachelor of Science in Forestry from the University of New Brunswick. My experience consists of contractor inspection/supervision, tree planting, pre-commercial thinning and public relations. I work well in a team and I thrive on responsibility. Willing to relocate and begin in May 1996.

PREST, Dwayne, Sidney, PO Box 13, Mooseland, NS BOJ 2J0. Tel: (902) 772 2082. Current address: 19 Forest Hill Rd., Apt. 48, Fredericton, NB E3B 4J9. Tel: (506) 455-4834.

I am currently a third year Forest Engineering student at the University of New Brunswick and am on schedule to graduate in the spring of 1998. I have had an opportunity to gain practical experience around the forest and forest operations. I have also been exposed to forest research and silviculture with my most recent summer employment. I enjoy being around the woods either when I am working or hunting and fishing. I would like to eventually work in the Maritimes but am planning on going out west once I graduate.

FIRN, Jennifer, 89 McCaul St., Apt. 313, Toronto, ON M5T $2 \times 3$.

Hard working and enthusiastic graduating forestry student looking for an operational position in silviculture, forest planning or harvesting operations. Have acquired valuable theoretical knowledge and functional skills in the area of silviculture. Other skills include, forest mensuration, photo-interpretation, photogrammetry, GIS, statistical analysis, data collection, and experimental design. Have developed excellent leadership, and oral and written communication skills.

DANG, Zhongyu. Faculty of Forestry, Lakehead University, 955 Oliver Rd, Thunder Bay, ON. P7B 5E1. Fax: (807) 343-81 16. Tel: (807) 343-841 1 (Office), (807) 344-6108 (Home).
Interest: forest entomology or pathology. Availability: from mid-April '96. Education: May ' 94 - April ' 96, MSc in forestry entomology at Lakehead University; Nov. '86 -Aug. '87, insect rearing at German Federal Institute of Biocontrol; Sept. ' 80 - July ' 84 , BSc in forest pest control at Beijing Forestry University. Employment: 10 years in forest entomology; 2 years in forest pathology.

WONG, Anne. Box 370, 40 Willcocks St., Toronto, ON M5S 1C6. Tel: (416) 5962426 or (416) $490-8571$ (after 3 May 1996).

Graduating Bsc.F. University of Toronto. Work experience in Timber cruising, regeneration surveys, small mammal project, data collection, and permanent sample plot measurements. Skills include organization, oral communication, computers, mensuration, and forest ecosystem classification. Worked in industry and government and have gained invaluable experience that will benefit future employers.

EAGLES, Beth. 837 York St., Fredericton, NB E3B 3R9 Tel: (506) 454-4303, e-mail:wloa@unb.ca.

1996 University of New Brunswick Graduate. Available to work starting in May 1996. Canada Scholar with work experience in regeneration surveys, cruising, entomology, and radio telemetry. Avid interest in wildlife management, ecology and human relations. Extra Curricular involvement includes UNB Forestry Association member, CIF member, Wildlife Society member, and UNB Wildlife Society President.

BOULIANE, Simon, 3440, rue Massart, Sainte-Foy (Québec), GIW 2N4. Tél. (418) 653-8009.

Baccalauréat en foresterie, aménagement des ressources forestières. Inventaires dendrométriques en pépinière et en plantation expérimentale. Évaluation de la santé (insectes, maladies) des arbres dans un parc fédéral. Établissement et suivi de dispositifs expérimentaux en génétique (croisements dirigés) et entomologie (TBE). Analyses dendrométriques de sapins beaumiers à l'aide du logiciel Windendro.

Bachelor's degree in Forestry, forest resources management. Measurement of plants in nurseries. Statistical analysis of genetics experimentation. Evaluation of tree health (diseases, insects) in a federal park. Follow-up of experimental tests in genetics (progeny test and controlled crossing) and entomology (spruce budworm). Measurement of balsalm fir stem with Windendro software. 